\title{
Pound per Square Inch
}

National Cancer Institute

\section{Source}

National Cancer Institute. Pound per Square Inch. NCI Thesaurus. Code C67334.

A traditional unit of pressure equivalent to 6.894757 kilopascals, or 703.0696 kilograms

per square meter, or 51.71507 millimeters of mercury. 